Digital Press Social Sciences and Humanities

Non-Formal Educational Institutions Provider's Readiness in the Implementation of the Regulation of the Minister of Education and Culture of the Republic of Indonesia No. 9 of 2020

Alim Harun Pamungkas

Proceeding of The Non-Formal Education International Conference 2020

Alim Harun Pamungkas, Jamaris, Solfema (eds) 


\title{
Non-Formal Educational Institutions Provider's Readiness in the Implementation of the Regulation of the Minister of Education and Culture of the Republic of Indonesia No. 9 of 2020
}

\author{
Alim Harun Pamungkas \\ Department of Non-Formal Education Universitas Negeri Padang, Padang, Indonesia \\ e-mail: alimharun@fip.unp.ac.id
}

\begin{abstract}
Changes in policy within the Ministry of Education and Culture of the Republic of Indonesia in 2020 manifested from the issuance of Minister of Education and Culture Regulation (Permendikbud) No. 9 of 2020. This policy is a change from the Minister of Education and Culture Regulation 45 of 2019. The policy contained in this Ministerial Regulation is a change in the structure of the Organization of Work Procedures (OTK) at the Ministry of Education and Culture. One of them is the loss of the Directorate General of Early Childhood Education and Community Education (Dirjen PAUD Dikmas) which merges into the Directorate General of Early Childhood Education, Elementary, Middle. This can give rise to pros or cons responses to policy implementers at the national level. The implications of the implementation of this policy were felt by the organizers of the Non-Formal Education Institutions in the City of Padang.
\end{abstract}

\section{Keywords}

educational policy, non-formal education, policy response

\section{Introduction}

Minister of Education and Culture Regulation 9 of 2020 is a policy that was born as an amendment to the Minister of Education and Culture Regulation 45 of 2019. In this regulation, there are 294 changes from the previous regulation. Changes occurred because of the emergence of pros and cons to the previous Work Administration Structure. The policy contained in this ministerial regulation is a change in the Work Administration Structure at the Ministry of Education and Culture of the Republic of Indonesia. One of them is the loss of the Directorate General of Early Childhood Education and Community Education/Dirjen PAUD Dikmas which merged into the Directorate General of Early Childhood Education, Primary, Secondary/Dirjen PAUD, Dasar, dan Menengah (Kementerian Pendidikan dan Kebudayaan, 2019).

In addition, the transfer of the course and training management structure from the previous under the Directorate of Course and Training under the Directorate General of Early Childhood Education and Community Education was moved under the structure of the Directorate General of Vocational Education with a new name as the Directorate of Courses and Training (Kementerian Pendidikan dan Kebudayaan, 2019). It will require a situation of adjustment from non-formal education providers at the regional to central levels. In particular, LKP and Community Learning Center/PKBM as well as SPNF SKB in Cities/Regencies.

This raises a pro or contra response to policy implementers at the national level. One of them was a protest carried out by IKAPENFI (the Association of Informal Nonformal Education Academics) and several alliances for non-formal education administrators and providers (Azhar, 2020; Fathurrohman, 2020; Priyo, 2020; Yunelia, 2020). The implications of policy implementation are felt by the delivery of non-formal education, such as LKP (Course and Training Institute), PKBM (Community Learning Center), and Community Learning Center (SPNF SKB) in Cities/Regencies. The number is certainly not small, even quoting 19,743 institutions, with details of 9,754 being private Community Learning Centers (PKBM), 
9,554 LKPs, and 435 stating Learning Centers (SKB) (Direktorat Jenderal PAUD dan Dikmas, n.d.). Especially in West Sumatra Province, there are 418 non-formal education units and Padang is in the first place with 69 non-formal education units with details of 32 PKBM, 35 LKP, and 2 SKB (Direktorat Jenderal PAUD dan Dikmas, n.d.).

Changes in the Organizational Structure of Work (OTK) certainly require an adjustment situation from non-formal education providers at the regional level, such as non-formal education providers in Padang, particularly LKP and PKBM, and SPNF SKB. Readiness is the keyword determining the success or failure of this change (Armenakis \& Bedeian, 1999). For this reason, it is important to make initial efforts to see this readiness through the response of non-formal education providers regarding the change in the Work Administration Structure (OTK). In the context of policy implementation, readiness or preconditions include four things, namely communication, resources, dispositions or attitudes of the implementer, and organizational structure including bureaucratic workflow procedures (Akib, 2010). Attention to readiness is important so that this change in SOTK does not lead to resistance. As stated by (Robbins \& Judge, 2013) that change often leads to failure because many members of the organization resist (are resistant) to change because they perceive change as something that is threatening.

Therefore, this article tries to conduct an initial study related to the readiness of non-formal education providers in the City of Padang for changes in the Work Administration Organization (OTK) of the Ministry of Education and Culture of the Republic of Indonesia in accordance with the Minister of Education and Culture Regulation 9 of 2020. This can be seen from the response of non-formal education providers, both private and government in Padang, which is focused on two policy implementation policies, namely the communication aspect of Minister of Education and Culture Regulation 9 of 2020. This study is expected to be a consideration for the government in making the changes to the Work Administration Organization (OTK) of the Ministry of Education and Culture of the Republic of Indonesia in accordance with Minister of Education and Culture Regulation 9 of 2020 so that this regulation does not experience resistance which leads to the failure of providing non-formal education services.

\section{Methods}

The research method used is descriptive quantitative. Methods of data collection by distributing questionnaires in the form of google form, and documentation study. Data processing was carried out before conducting data analysis by coding, data classification, and data reduction. In data analysis, two analyzes were carried out, both within and at each/between sites. All analysis results are discussed using policy theory to draw conclusions.

The population of this study was the non-formal education providers in the city of Padang, namely 69 people with an explanation of 1 person from each non-formal education provider, totaling 69 institutions. The sample in this study was 46 people. The variable in this study is the response variable and is defined as an impression, view, opinion of non-formal education providers in the city of Padang towards Minister of Education and Culture Regulation 9 of 2020 based on aspects of knowledge, assessment, and acceptance.

\section{Result and Discussion}

In terms of readiness or preconditions for policy implementation, it can be carried out well in relation to a series of communication processes, such as the process of delivering information (transmission), clarity of information, and consistency of information conveyed to the implementer (Akib, 2010; Ramdhani \& Ramdhani, 2017). The findings in this study are in that since the issuance of Minister of Education and Culture Regulation 9/2020 on February 12, 2020, until this research was conducted in June 2020, not all non-formal educational institutions in the city of Padang are aware of these regulations. From the research findings, from 46 managers representing their respective institutions, only 30 or $65.2 \%$ knew the rules, while 16 or $34.8 \%$ did not know the rules. Furthermore, of the 30 institutions, only 24 managers read the contents of the Minister of Education and Culture Regulation 9/2020. 
These findings imply that the process of delivering policy information from policymakers to policy implementers, in this case, non-formal education providers in the city of Padang, is not going well. This of course must be a serious concern for policymakers, in this case, namely the Indonesian Ministry of Education and Culture. Whereas the transmission aspect requires that a policy is not only conveyed to policy implementers but also the policy target group and other parties with an interest either directly or indirectly in the policy (Ratri, 2014).

Furthermore, in the aspect of clarity, policies that have been transmitted to policy implementers or other related parties must be able to receive information clearly, so that the aims, objectives, targets, and substance of the policy can be implemented properly (Afandi \& Warjio, 2015; Ratri, 2014). In this case, Minister of Education and Culture Regulation 9/2020 which contains significant changes to the Organizational Structure of Work Procedures (OTK) for non-formal education, in which the loss of the Directorate General of Early Childhood Education and Community Education (Dirjen PAUD Dikmas) merged into the Directorate General of Early Childhood Education, Elementary, Secondary, with a nomenclature at the directorate level, namely the Directorate of Community Education and Special Education. Subsequently, the transfer of the course and training management structure from the previous one under the umbrella of the Directorate of Course and Training under the Directorate General of Early Childhood Education was moved under the structure of the Directorate General of Vocational Education with a new name as the Directorate of Courses and Training (Kementerian Pendidikan dan Kebudayaan, 2019). In the findings of researchers, as many as $65.2 \%$ or 30 non-formal education providers in the city of Padang are aware of these changes. However, only $37 \%$ or 17 non-formal education providers in the city of Padang know the purpose of the change in the non-formal education Work Administration Structure (OTK).

The findings of these researchers explicitly state that the purpose of the change in the Organizational Structure for the Work Procedure (OTK) of non-formal education is still not fully understood by nonformal education providers in Padang City. This of course will lead to further consequences, namely the occurrence of resistance (rejection), where the percentage of non-formal education providers in Padang to Minister of Education and Culture Regulation 9/2020 is quite high, namely $71.7 \%$ or 33 of 46 nonformal education providers in Padang. This is in line with the findings of research conducted by (Afandi \& Warjio, 2015) that if the delivery of information about the goals and objectives of a policy to the target group is not clear, resistance from the target group may occur.

Furthermore, in the aspect of information channels, the findings of the researchers revealed that only $8.7 \%$ or 4 organizers obtained information from counselling and socialization and $23.9 \%$ or 11 people obtained information from reading copies of documents. While the remaining $67.4 \%$ or 31 organizers obtained information from television news, print and online media news, and. This is, of course, a particular concern considering that the two information channels, namely television coverage, and print and online media news do not contain a comprehensive explanation of the regulation.

To overcome resistance to changes in the non-formal education Work Administration Structure (OTK) contained in Minister of Education and Culture Regulation 9/2020, according to (Palmer, Dunford, \& Akin, 2008). It is necessary to make efforts to socialize the benefits of change, both for the individual and for the organization, the steps that will be taken, and to ensure that changes do not interfere with anyone's interests. The same thing was also expressed by Kotter \& Schlesinger (2008) that to overcome resistance can be done by combining education and communication. The policy target party is first given education, communicating the needs and logic of change, for example through socialization, presentations, or group discussions. Furthermore, according to Pott \& Marsh (2004) To overcome resistance to change, several things can also be done, namely making communication plans about change, making learning plans, and making reward plans.

\section{Conclusions}

Based on the presentation of the results and discussion, it can be concluded that the readiness or precondition of non-formal education providers in the city of Padang, specifically the communication aspect in implementing the Minister of Education and Culture Regulation 9/2020 policy which contains changes to the Organizational Structure for Non-formal education Work Procedures (OTK), namely: First, aspects of the delivery process information (transmission), there are still many non-formal education providers in the city of Padang who do not know and read Minister of Education and Culture Regulation 
$9 / 2020$. Second, the aspect of information clarity, $65.2 \%$, or 30 non-formal education providers in the city of Padang are aware of changes in the change in the organizational structure of non-formal education (OTK) contained in Minister of Education and Culture Regulation 9/2020. However, only 37\% or 17 objectives of the change. Third, the problem with the transmission and clarity of information received by non-formal education providers in the city of Padang ultimately has a consequence of the high percentage of rejection of the change in the Organizational Structure of the Work Procedure (OTK) of non-formal education contained in Minister of Education and Culture Regulation 9/2020, namely $71.7 \%$ or 33 of 46 non-formal education providers in the city of Padang.

\section{References}

Afandi, M. I., \& Warjio, W. (2015). Implementasi Peraturan Daerah Kabupaten Asahan Nomor 11 Tahun 2011 Tentang Pajak Daerah dalam Pencapaian Target Pajak Bumi dan Bangunan Perdesaan dan Perkotaan (Studi Deskriptif di Kelurahan Bunut Barat Kecamatan Kota Kisaran Barat). Jurnal Administrasi Publik, 5(2), 132-153. https://doi.org/https://doi.org/10.31289/jap.v5i2.70

Akib, H. (2010). Implementasi Kebijakan: Apa, Mengapa, dan Bagaimana. Jurnal Administrasi Publik, 1(1), 111. https://doi.org/https://doi.org/10.26858/jiap.v1i1.289

Armenakis, A. A., \& Bedeian, A. G. (1999). Organizational Change: A Review of Theory and Research in the 1990s. Journal of Management, 25(3), 293-315. https://doi.org/10.1177/014920639902500303

Azhar, R. (2020). Struktur Organisasi Kemendikbud Berubah. Retrieved from https://bengkuluekspress.com/struktur-organisasi-kemendikbud-berubah/

Direktorat Jenderal PAUD dan Dikmas. (n.d.). Rekapitulasi Satuan Pendidikan PAUD dan Dikmas.

Fathurrohman. (2020, January 16). Pendidikan Nonformal dan Informal Didesak Masuk ke Vokasi.

Kementerian Pendidikan dan Kebudayaan. Permendikbud Republik Indonesia Tentang Perubahan Atas Peraturan Menteri Pendidikan dan Kebudayaan Nomor 45 Tahun 2019 Tentang Organisasi dan Tata Kerja. , (2019).

Kotter, J. P., \& Schlesinger, L. A. (2008). Choosing Strategies for Change. Harvard Business Review, 86, 7-8.

Palmer, I., Dunford, R., \& Akin, G. (2008). Managing Organizational Change: A Multiple Perspectives Approach (2nd ed.). McGraw-Hill Education.

Pott, R., \& Marsh, J. L. (2004). Managing Change for Success. Ducan Baird Publishers.

Priyo, B. S. (2020. (2020, February 3). Perpres 82/2019 Ditolak Publik, Nadiem Pertimbangkan Revisi Permendikbud 45/2019. Retrieved from https://www.suarakarya.id/detail/106509/Perpres-822019Ditolak-Publik-Nadiem-Pertimbangkan-Revisi-Permendikbud-452019

Ramdhani, A., \& Ramdhani, M. A. (2017). Konsep Umum Pelaksanaan Kebijakan Publik. Jurnal Publik, 11(1), $1-12$.

Ratri, D. K. (2014). Implementasi Peraturan Walikota Nomor 36 Tahun 2013 Tentang Kebijakan Kota Layak Anak. Jurnal Ilmu Pemerintahan UB, 1(2), 1-13.

Robbins, S. P., \& Judge, T. (2013). Organizational Behaviour. Pearson Education.

Yunelia, I. (2020. (2020, January 14). Komisi X Minta Pendidikan Nonformal Dimasukkan ke Ditjen Vokas. Retrieved from https://www.medcom.id/pendidikan/news-pendidikan/gNQ0QxaK-komisi-x-mintapendidikan-nonformal-dimasukkan-ke-ditjen-vokasi 